\title{
Plesiommata zanolae sp.n. (Hemiptera, Auchenorrhyncha, Cicadellidae) do Mato Grosso, Brasil ${ }^{1}$
}

\author{
Rodney Ramiro Cavichioli ${ }^{2}$
}

\begin{abstract}
Plesiommata zanolae sp.n. (Hemiptera, Auchenorrhyncha, Cicadellidae) from Mato Grosso, Brazil. A new species of Plesiommata Provancher, 1889 is described, from Mato Grosso, Brazil. P. zanolae is similar with P. corniculata and $P$. mollicula, but its different in the structural aspect male genitalia and coloration. KEY WORDS. Auchenorrhyncha, Cicadellidae, Plesionimata zanolae
\end{abstract}

Segundo Young (1977), Plesiommata Provancher, 1889 ocorre do leste dos Estados Unidos até a Argentina e possui cinco espécies: P. alcorni Beamer, 1953, P. corniculata Young, 1977, P. mollicella (Fowler, 1900), P. mollicula (Fowler, 1900) e P. tripunctata (Fitch, 1851).

\section{Plesiommata zanolae sp.n.}

Figs 1-8

Localidade tipo. Holótipo macho, BrasiL, Mato Grosso: Nova Xavantina, 18/VIII/1997, K. Zanol leg. (DZUP, Coleção Entomológica Pe. Jesus Santiago Moure, Departamento de Zoologia, Universidade Federal do Paraná). Parátipo fêmea Mato Grosso: Ribeirão Cascalheira, 12/VIII/1997, K. Zanol leg. (DZUP).

Holótipo medidas em milímetros. Comprimento total: 5,00; comprimento mediano da cabeça: 0,44; distância transocular: 1,36; distância interocular: 0,76 ; comprimento mediano do pronoto: 0,72 ; distância entre os úmeros: 1,16 ; comprimento das tégminas: 3,96; largura máxima das tégminas: 1,08. Cabeça, em vista dorsal, não pronunciada, de comprimento mediano aproximadamente $1 / 3$ da distância transocular e 4/7 da interocular; superfície dorsal lisa, margem anterior levemente angulada; lóbulos supra-antenais não protuberantes dorsalmente; ocelos situados atrás da linha imaginária que tangencia os bordos anteriores dos olhos; fronte convexa, com impressões musculares evidentes, na porção mediana finamente granulada; clípeo, de perfil contínuo ao da fronte. Pronoto mais estreito do que a cabeça, de comprimento mediano 5/8 da largura entre os úmeros; margens laterais, levemente convergentes anteriormente, com a margem posterior emarginada na porção mediana. Tégminas 3,6 vezes mais longas do que largas, com a porção apical membranosa; célula anteapical externa fechada, as duas internas, abertas; com

1) Contribuição número 1065 do Departamento de Zoologia, Universidade Federal do Paraná.

2) Departamento de Zoologia, Universidade Federal do Paraná. Caixa Postal 19020, 81531-990 Curitiba, Paraná, Brasil.

E-mail: cavich@bio.ufpr.br 

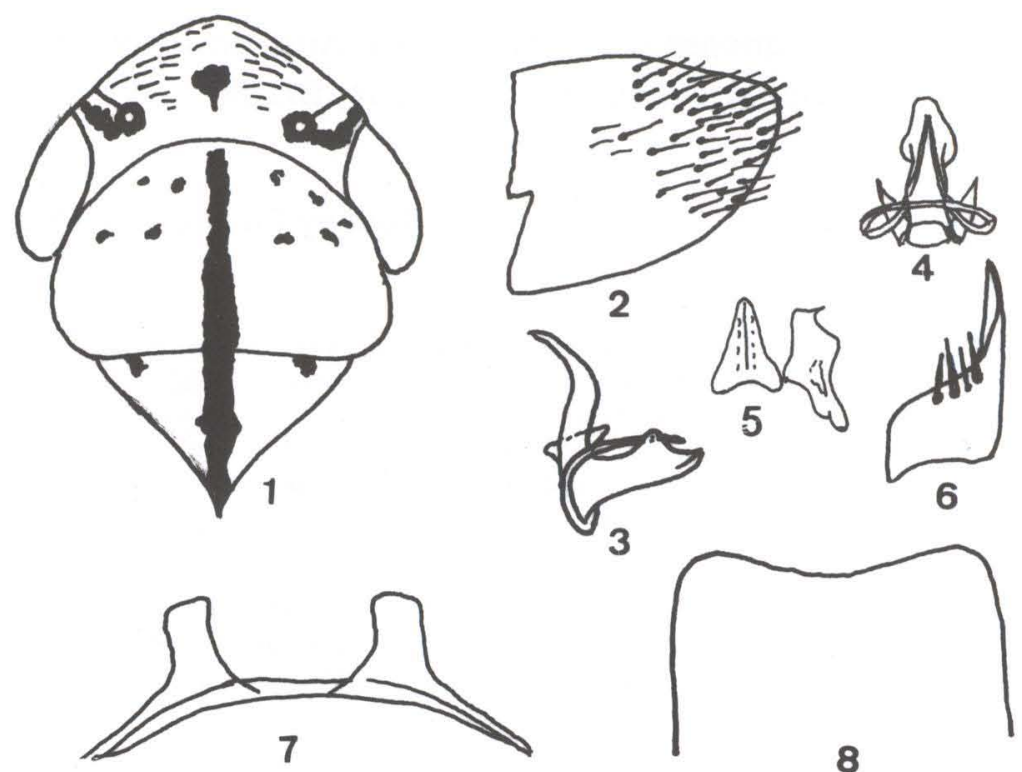

Figs 1-8. Plesiommata zanolae sp.n..(1-7) Holótipo:(1) cabeça, pronoto e escutelo, em vista dorsal; (2) Pigóforo, em vista lateral; (3) edeago, em vista lateral; (4) edeago, em vista dorsal; (5) conetivo e estilo, em vista dorsal; (6) placa subgenital, em vista ventral; (7) apódemas na base do esternito III, em vista ventral; (8) esternito VII da fêmea, em vista ventral.

quatro células apicais, sendo a terceira mais proximal do que a quarta; venação nítida, sem plexo de veias ou extranumerárias. Base esternito abdominal III do macho com uma conspícua apódema, formando duas projeções posteriores, delgadas e truncadas apicalmente.

Pigóforo, lateralmente, quase tão largo basalmente quanto longo, margem apical arredondada, com macrocerdas distribuídas do terço basal até o ápice, processos ausentes. Placa subgenital triangular, bipartida, comprimento igual a metade do comprimento do pigóforo, larga na base e afilada abuptamente do meio para o ápice, com uma série de macrocerdas na parte basal. Estilos curtos, atingindo o ápice do conetivo, com lobo pré-apical, ápice em forma de um pé. Conetivo em forma de "Y" invertido, com uma conspícua carena dorso-mediana. Edeago subcilíndrico, com duas abas látero-dorsais próximas do ápice que termina em ponta, em vista ventral, o ápice é cordiforme. Edeago com dois processos basais ântero-dorsais, curvados e voltados para trás sobre a margem dorsal.

Esternito VII da fêmea, curto, com a margem apical truncada e retilínea e as margens látero-apicais arredondadas.

Coloração geral marrom-claro. Cabeça, em vista dorsal, com as impressões musculares pigmentadas de marrom-escuro; coroa com uma mancha pequena, de forma irregular, marrom-escuro. Pronoto, escutelo e margem anal das tégminas, com uma faixa mediana estreita, marrom-escuro, veias escurecidas. Pronoto com 
várias pequenas manchas marrom-escuro, de forma irregular ao lado da faixa contínua.

Discussão. Todas as espécies descritas de Plesiommata apresentam um par de processos basais, curvados ântero-dorsalmente e estendo-se para a região apical do edeago sobre sua margem dorsal. $P$. zanolae sp.n. apresenta o ápice do edeago semelhante àquele de $P$. mollicula Fowler, 1900, em vista ventral, sendo semelhante à $P$. corniculata Young, 1977. Difere dessas espécies por apresentar um comprimento total maior que $P$. corniculata e diferindo de todas pela sua coloração geral e estrutura do edeago.

Etimologia. Essa espécie é dedicada a Profa. Dra. Keti Maria Rocha Zanol, colega de trabalho e coletora do material.

\section{REFERÊNCIA BIBLIOGRÁFICA}

Young, D.A. 1977. Taxonomic study of the Cicadellinae (Homoptera: Cicadellidae). Part 2. New World Cicadellini and the genus Cicadella. Bull. N. Carol. agric. Exp. Stn 239: VI+1135.

Recebido em 06.VIII.1998; aceito em 23.IX.1999. 